\title{
Pusan 2001
}

\author{
By Ron Holloway
}

Fall 2001 Issue of KINEMA

\section{5th PUSAN INTERNATIONAL FILM FESTIVAL AND 3rd PUSAN PROMOTION PLAN}

Look no further -- there just isn't another festival on the circuit that specializes in Asian cinema better and with more insight than the Pusan International Film Festival -- together with its twin, the Pusan Promotion Plan (covered in a separate report). Indeed, this showcase of Asia cinema is generally recognized by visiting critics as the one to visit if you're a bonafide cineaste interested in production from all corners of the Near and Far East.

The 5th PIFF (6-14 October 2000) will go down in history as a chronicle of events as well as a festival of films. No sooner had it got underway than word was out that visits between long separated families in North and South Korean were now possible. In addition, local media commentators were discussing a Nobel Peace Prize for South Korean President Kim Dae-jung -- the honour was announced a few weeks later. Perhaps most significant of all, Park Chan-wook's JSA (short for Joint Security Area), a feature film set right on the no-man's-land strip between north and south, was breaking the home box office record. And since JSA, part courtroom thriller, part forbidden friendship between young border guards on both sides, was a daily cinema attraction in a large, and often packed, venue right next door to the full houses of the festival, foreign guests were simply advised to see it on their own as much of the production (particularly the courtroom scenes) was filmed in English anyway.

Pusan opened in the spacious Yachtang Centre Outdoor Theatre (seating 10,000 comfortably) with Buddadeb Dasgupta's The Wrestlers (India) and closed with Wong Kar-wai's In the Mood for Love (Hong Kong-China). Altogether, festival director Kim Dong-ho programmed well over a hundred Asian features, shorts, and documentaries in nine overlapping sections, as follows: 28 awarded features in "A Window on Asian Cinema"; 12 aspiring Asian talents in the "New Currents" program; 12 new features in the "Korean Panorama"; 41 Asian shorts, documentaries, and animation films in the "Wide Angle" section; 5 popular Asian features in the "Open Cinema" program at the Yachtang venue; a retrospective of 6 popular hits based on Korean literature titled "Everlasting Cinema of the Classic: Choon-Hyang Jeon"; 8 films in the "Salaam Cinema! Films of the Makhmalbaf Family" tribute; 9 films in a "Cinema Over Tien Shan Mountain: Special on Central Asian Cinema" spotlight, and 8 Asian-oriented films in the "World Cinema" selection.

Appropriately, Romuald Karmakar's Manila (Germany) was programmed in the "World Cinema" section. Awarded the Silver Leopard at Locarno, this biting satire on the foibles of German tourists stranded at an airport in the Philippines runs over a demanding two-hour stretch. But just when one has about gotten his fill of the banalities of the tourist trade, to say nothing of the senseless palaver pouring from the mouths of pigeon-brained fools, Karmakar ends it all on a comic note: an improvised chorus number right out of Verdi's "Nabucco"!

Given that Korea's rigid quota system effectively prevents inroads from the Hollywood studios, Pusan audiences are a rich viewing receptacle for Asian films previously awarded at Western festivals. Four previous Cannes entries -- Im Kwon-taek's Chunhyang (Korea, based on the Choon-hyang classic), Nagisa Oshima's Gohatto (Japan, a Samurai film with a homosexual twist), Edward Wang's A One and a Two (Taiwan-Japan, a family drama about the generation gap), Shinji Aoyama's Eureka (Japan, inspired by John Ford's The Searchers), and Jiang Wen's Devils on the Door Step (China, a WW2 tale that has yet to be released in China) -- were among the first to sell out in the "Window on Asian Cinema" section.

Just as popular was Jafar Panahi's The Circle (Iran). Although awarded the Golden Lion at Venice, this biting indictment of the oppression of women in today's Iran may never pass the censor board at home. In Pusan, however, it was viewed as a fitting companion to the humane messages found in the diverse films of the Makhmalbaf family retrospective. Thus it came as no surprise when Marziyeh Meshkini, mother of Samira Makhmalbaf, was voted the New Currents Award for her debut film, The Day I Became a Woman (Iran). This outspoken appeal to respect the dignity of women is remarkable for the metaphor Meshkini uses to state her case: a woman on a bicycle is seen pedalling furiously down a causeway, pursued by men 
on horseback intent on overtaking her and returning her to a promised husband. And she is only one of a crowd of women on bicycles, all clothed in black.

As for the films in the Korean Panorama, too many young directors appear to be imitating American and European models while leaning heavily on digital technology and sometimes dispensing with a story-line altogether. Often, the titles alone (Tears, Secret Tears, Post Concussion, Real Fiction, La Belle, Il Mare) are a giveaway, and the life-style of the fun generation (mobile telephones, computer games, sexual freedom, bored youth) becomes almost an end in itself. One authentic auteur in the group, however, already has a broad international following: Hong Sang-soo. Awarded in Rotterdam and Vancouver, Hong's trilogy on alienated youth -- The Day a Pig Fell into the Well (1996), The Power of Kangwon Province (1998), and Oh! Soo-Jung (aka Virgin Stripped Bare by Her Bachelors) -- are all slow-moving, minimalist films whose strong emotional impact is derived from precise images and reserved acting. In Virgin Stripped Bare by Her Bachelors (invited to the Certain Regard at Cannes), filmed in black-and-white, Hong recounts five versions of the same story to emphasize that relations between a young woman, a virgin who wants to remain so, and her two male friends will always vary according to perspectives, viewpoints, circumstances. Place the action within the context of a script being written for a film production, and the flip-sides of fiction and reality also enter the picture.

One controversial Chinese film was a no-show at Pusan: Wang Shuo's Father, banned by authorities in 1996, but awarded at the Golden Leopard at the last Locarno festival when an illegal print mysteriously surfaced. Set in contemporary China, this appears at first to be a rather typical story of the generation gap -- about a son rebelling against his father. Save in this case the father is the chairman of a labour union and an official of the communist party.

\section{3rd Pusan Promotion Plan}

There was enough awarded talent among the 22 projects from 12 film lands selected for this year's 3rd Pusan Promotion Plan (PPP) to satisfy even the most particular and persnickety of Asian cineastes.

Take, for example, the Indian project: Shaji Karun's The Sea. The cameraman-turned-director collaborated on the award-winning features of the late Govind Aravindan, Kerala's pioneer master. When the Trivandrumbased filmmaker directed his debut feature Birth (1988), it was invited to Cannes and won a Silver Leopard at Locarno. Shaji's My Own (1994) and The Last Dance (1999), both invited to Cannes, confirmed his talents as a poet with an affinity to art, music, and folk traditions of Kerala. In The Sea, the story of a decaying family relationship, Shaji probes human behaviour through its most sensitive form of artistic expression -music.

Another outstanding director is Tsai Ming-liang. Awarded a Golden Lion at Venice for Vive l'amour (1994), followed by a Silver Bear at Berlin for The River (1996) and an invitation to compete at Cannes with The Hole (1998), the Malaysian-born Taiwanese director intends to return to the land of his birth to make his PPP project, Dark Circles. As in all of Tsai's films, the focus is on an outsider caught in a web of sex and money, of events and intrigue beyond his control. When the identity-seeking protagonist suffers a black eye, it serves as a giveaway symbol of his illegal status.

Darejan Omirbaev is a key figure in the Kazakh Film Wave, reckoned by some critics as the strongest national cinema in the former Soviet republics. His Kairat (1991) won a Silver Leopard at Locarno, Kardigramma (1995) competed at Venice, and Killer (1998) was one of the highlights of the Certain Regard at Cannes -taken altogether, they form a stylistic trilogy of Bressonian minimalist cinema. Omirbaev's PPP project, The Road, has an autobiographical feel to it: a film director living in Almaty receives a telegram from a village informing him that his mother is ill, thereby prompting the decision to leave his family and hit the road to be with her.

Ardak Amirkulov, another Kazakh director, is remembered for The Fall of Otrar (1991), a landmark film that restored national pride by breaking the Soviet barrier on Muslim traditions. Awarded a FIPRESCI prize at Montreal, it was followed by Abai (1992), awarded at Tashkent, and Rustem's Notes with Sketches (1998), presented at Berlin. In Drumming, Amirkulov's PPP project, he probes the contrasting lifestyles of 
the young generation on the crossroads between European and Oriental traditions.

Of the five Korean projects, tops on the PPP list is Jang Sun-woo's Resurrection of the Little Match Seller, in which the Hans Christian Andersen heroine is rescued from freezing to death by an electronic game. Jang is remembered for having stormed the 1999 Venice festival with the scandalous Lies, viewed by some critics as the hottest production on Asian celluloid since Nagisa Oshima's In the Realm of the Senses.

Remember Yu Lik-wai -- the Chinese director whose Love Will Tear Us Apart (1999) competed at Cannes as a Hong Kong entry and was awarded the FIPRESCI Prize? Yu's Korean project Pusan Story narrates the painful odyssey of an adopted Korean-American who longs to discover her true identity. Zhang Yuan -- another talented Chinese director, who made the sexually controversial East Palace, West Palace (1996) and was awarded Best Director at Venice last year for Seventeen (1999) -- is pitching Hainan Plus at Pusan, about a young man who obeys a beautiful lady in his dreams and leaves everything behind to go to Hainan and seek the love of his life.

Clara Law, awarded the Golden Leopard at Locarno for Autumn Moon (1992) and present this year at Venice with The Goddess of 1967 (2000), has set her Hong Kong-Australian project The Mechanical Bird in the deserts of Down Under, where a quest begins to uncover a dark secret of the past. Similarly, Lou Ye, a Tiger Award winner at Rotterdam for Suzhou River (1999), is pitching The Summer Palace at PPP, about "human emotions beyond earthly control."

Iwai Shunji's Japanese project All About Lili Chou-Chou teases as much as did his previous Undo (1994), a NETPAC award-winner at the Berlinale's Forum about a married woman who weaves a self-made web of unrequited love and longing. Harada Masato's project Pistolero is set in the year "200X," a futuristic time when military police, drug addicts, and an amateur rock band free of the media wrangle wrestle for the same turf. His previous Spellbound (1999) was voted 12 nominations in the Japanese Academy Awards.

That's just half of the projects invited to the 3rd Pusan Promotion Project. Unfortunately, entries from Vietnam, Thailand, and the Philippines haven't even been mentioned, nor some projects from Hong Kong, China, Korea, and Japan.

Just as important were the panels and roundtables on the schedule. Panels on the Internet, the entertainment industry, and digital technology promise to be drawing cards. So, too, the roundtables on insurance and completion bonds, on "marketing from A to Z," on the current status of New Korean Cinema. No wonder, then, the number of registered guests has doubled over last year.

A final note: a welcomed financial increase from the industrial sector has paved the way for more purse awards. What more could be asked of this year's Pusan Promotion Plan?

\section{References}

\section{AWARDS}

New Currents Award

The Day I Became a Woman (Iran), Marziyeh Meshkini

\section{FIPRESCI Award}

Sunflower (Japan), Isao Yukisada

Special Mention: Tears (Korea), Im Sang-soo

NETPAC Award

Chunhyang (Korea), Im Kwon-taek

PSB Audience Award

Die Bad (Korea), Ryoo Seung-wan

Sonje Fund Award (Best Korea Short Film or Video)

Bardo (Korea), Yoon Young-ho 


\section{Woonpa Award (Best Korean Documentary)}

Sky-Blue Hometown (Korea), Kim So-young

\section{Author Information}

Ron HOLLOWAY (1933-2009) was an American critic, film historian, filmmaker and correspondent who adopted Europe as his home in the early fifties and spent much of his life in Berlin. He was an expert on the study of German cinema and against all odds produced, with his wife Dorothea, the journal German Film, keeping us up-to-date with the work of directors, producers and writers and the showing of German films around the world.

In 2007, Ron Holloway and his wife were awarded the Berlinale Camera Award. Ron also received the Bundesverdienstkreuz (German Cross of Merit), Polish Rings, Cannes Gold Medaille, the American Cinema Foundation Award, the Diploma for Support of Russian Cinema and an honorary award from the German Film Critics' Association.

Ron was also a valued contributor to Kinema for the past fifteen years. 